\title{
Variation of Linguistic Form of News Titles of Indonesian National Newspapers
}

\author{
Atiqa Sabardila (Corresponding author) \\ Indonesian Language Education, Universitas Muhammadiyah Surakarta, Indonesia \\ E-mail: as193@ums.ac.id \\ I Dewa Putu Wijana \\ Faculty of Culture Science, Universitas Gadjah Mada, Bulaksumur, Caturtunggal, Yogyakarta, 55281, Indonesia \\ E-mail: idp_wijana@yahoo.com \\ Suhandano \\ Faculty of Culture Science, Universitas Gadjah Mada, Bulaksumur, Caturtunggal, Yogyakarta, 55281, Indonesia \\ E-mail: suahandano_ugm@yahoo.com
}

Received: 05-04-2017

Accepted: 17-06-2017

Advance Access Published: September 2017

Published: 01-11-2017

doi:10.7575/aiac.ijalel.v.6n.6p.134

URL: http://dx.doi.org/10.7575/aiac.ijalel.v.6n.6p.134

\begin{abstract}
This descriptive-qualitative study aims at describing the linguistic form on news title. Related to data classification, this study uses segmenting immediate constituents technique. This technique is also utilized to separate the elements of the sentence function. The data is combined based on the similarities of their pattern and category. Furthermore, in order to classify the similarity of the meaning on the phrase or clause on title, this study provides the paraphrase and substitutes the constituent position of function in clause to recognize the arrangement. Moreover, in identifying the constituent of omitted clause, the technique is by inserting or expanding the structure of the title. The variation of the linguistic form is also based on whether or not the figurative language of the title appears. The news title is written by considering these several aspects: phonology, lexicon, grammatical, sentence modus, cohesion, and figurative language. Those aspects are intended to fulfill several functions, such as informing, influencing, preserving the social connection between the server and the receiver of the information or delivering the response about a phenomenon. Based on these several aspects, the characteristics of the linguistics of the titles give the practically ease of understanding for those who are learning to write the straight news discourse.
\end{abstract}

Keywords: news content, body of the news, principle element of news, reference

\section{Introduction}

A study about a linguistic form on the straight news in Indonesia has not been finished yet. It is due several problems. One of them is that there are not many news papers which can be the data source, the unit of the analysis is limited on the level of clause and sentence. Therefore, the variation of the news title writing of the straight news has not been patterned. Moreover, the variation of journalistic characteristic has not been identified completely.

The innovative approach of this current study is the description of the characteristics of the linguistic form of titles which are investigated from the level of phonological and discourse. Then, through this study, the productivity pattern of Indonesian languages clauses can become the evidence(s).

Further, the findings of this study prove that the variations of the title are pretty much flexible. They receive other variations to express the process of writing titles. Through the analysis of the findings, this study found its limitation of the concept of ellipsis. Ellipsis appears on the level of syntax and discourse. In the level of syntax, the constituent which is omitted can be investigated by its clause (i.e. clauses on titles). Moreover, in the level of discourse, the constituent that is neglected can be investigated through the clauses in the body of the news. It signs that the study of syntax should be prolonged to the discourse analysis.

Based on the news title reading, it depicts the genre of the news title that can be developed outside the basic patterns of Indonesian sentences. Furthermore, the news title is not provided as an example in Tata Bahasa Baku Bahasa Indonesia 'Book of Indonesian Language Standard Grammar'.

Through the pattern of the news title, it proves the appearance of the productivity and creativity in using the language that are connected to the new elements of the functions in the clause. The variations of the pattern are developed by 
sentences in the body of the news. The news title which has several patterns confirms the Indonesian language capability, such as merging to the local or foreign elements, or amalgamating to the archaic statement.

The problem statement of the current study, generally, is how the relationship between the title and the news content in the national newspaper. Based on this problem statement, then, it describes the variations of the linguistic form of the title of the Indonesian national newspapers.

Build upon the explained background of the study, the followings are the theoretical and practical significances of the study. The theoretical significances of the study covers (1) proving the journalistic variations, especially for the news writing that experiences the flexibility in taking other variations; (2) proving the productivity of the variation of the news writing, whether in the form of phonological, lexicon, or grammatical characteristic; and (3) proving the limitation of the ellipsis in the area of syntax and discourse.

Additionally, this study hopefully yields these practical significances: (1) helping the learners of language who are difficult to make an effective sentence; (2) proving that newspaper cannot be left behind since it is successful to develop the variation of the learning function; (3) proving that any utterances are proper to be entitled; and (4) providing examples of materials of syntax in the teaching-learning process comprehensively, i.e. started from word, phrase, sentence, and discourse. In addition, to build the readers' understanding towards this kind of study, this paper also provides several previous studies such as Sabardila (1997), Sumarno (2005), and Mulyati (2005) which are reviewed as follows.

Sabardila (2005) found the limited internal structure of clause, such as Subject-Predicate or the variation (PredicateSubject), Subject-Predicate-Object, Subject-Predicate-Adverb or the variation, Subject-Predicate-Complement, and clause with the omission of Subject (S) function. In this article, the title was identified based on the phonological, lexicon, grammatical and discourse characteristic.

A research conducted by Sumarno (2005) was about the variation of pattern on the functional element of the news title. Any patterns that appear were due to the application of the syntactical element in a news title. Besides, they were identified that there were deviations in writing news title from the standard principle of Indonesian language, such as the deletion of $\mathrm{S}$ in the simple sentence, the omission of subordinator and $\mathrm{S}$ minor clause, omission of subordinator and $\mathrm{S}$ main clause, subordinator and $\mathrm{S}$ minor clause that is not identical to the $\mathrm{S}$ main clause (dangling participle/misrelated participle), omission of $S$ in all clauses of equivalent sentence, omission of $S$ in all clauses of un-equivalent sentence, omission of subordinator and $\mathrm{S}$ of all clauses, and the use of word that is not suitable to its syntactical function.

Mulyati's (2005) investigation described the title of the news in the newspapers, described the omission, and described the factors that influenced the omission itself. The title of the news in the newspapers could be in the form of word, clause, phrase, clause, simple sentence, and broader sentence. The omission could be in the level of affix or word and phrase. The omission of dominant affix was the omission of affix $m e(N)$ - on the word that functions as predicate and it is a transitive-active verb. The factors that caused the omission were due to the limitation of the area, influence of conversation, and code-mixing.

Rohadi (2010) explained his research findings about the importance of humor towards human's life commotion. His dissertation gave confession about the function of humor that could allay the stressfulness. In his analysis about the news title, it was connected to the understanding of situation of readers' psychology, i.e. the provider of the news wanted to neglect the pressure due to the habitual activity by postulating any severe things easily.

Wijana (2011) investigated the slang language of Indonesian youths. It was concluded that the appearance of the Indonesian slang gave contribution to the development of Indonesian language generally. The phenomena of linguistic in newspaper, through utterance on the news title, proved that the development of slang within youths, such as what was exampled by Wijana himself, did not become any threats towards the Indonesian language standard. Journalist understands the psychological aspect of the readers that mostly they work extremely. Furthermore, it was necessary to provide an affluence of the news presentation towards the thoughtful thing (news).

Marliana's and Puryanto's (2009) found that newspapers had not been appropriate to the standard Indonesian language principle. However, this dissertation proved that through the news title, the patterns of vary clauses could be applied in arranging title.

Moreover, the investigation conducted by Kesuma (2005) about the function of Adverb (A) from categorical and its semantic role and Baryadi (2007) about the differences of the placement of minor clause in the arrangement of clause could help to identify the function on the clause of title and on the sentence of the body of the news. In addition, through the title, it proved whether the appearance of the function signed the appearance of other clauses in the news title.

The description about the news title that is investigated from the level of grammatical of clause and the variation of the pattern are investigated by structuralism approach. The level of phrase and clause are the grammatical unit that enables to be organized as a title. This approach is relevant to describe the variation of the pattern. Therefore, the structure in the analysis of sentence pattern is used to describe the phonological and lexical characteristic in arranging title, coherence and cohesion in the relation of title and the body of the news, the description of figurative language, and the imagery device in the title structure. Another approach is functionalism. This function is correlated to the function of communication of the newspaper, especially the function of the news and the title of the news. Investigating the 
correlation between the title and the news content is done by hermeneutic approach. The utterance of the title is interpreted based on the component formula $5 \mathrm{~W}+1 \mathrm{H}$.

Furthermore, the concept of tagmemic is applied to identify the linguistic form on title. Tagmen is an element from a grammatical construction which has four dimensions: slot, class, role, and cohesion. On the other level, generally, it is in the forms of nucleus, and margin. Filler class is a dimension of tagmemic which is the real appearance of slot. This real appearance can be in the form of morpheme, word, phrase, clause, sentence, paragraph, monolog, dialogue, and discourse. Class can also be broken down into subclass, such as noun, verb, adjective, noun phrase, verb phrase, adjective phrase, transitive clause, intransitive clause. Moreover, role is one of the dimensions which are the porter of the function of tagmen (Pike \& Pike, 1977: 489).

To identify whether or not there is a figurative language on title, it is connected to the concept of modern stylistic which analyzes the formal characteristic, i.e. (a) phonology, such as the patterns of utterance sound, verse, and rhyme; (b) syntax, such as types of sentence structure, (c) lexical covers abstract and concrete word, relative frequency of noun, verb, and adjective, and (d) rhetoric, that is the characteristic of using figurative language and parable (Ratna, 2009: 22). Furthermore, since the title writing is intended to generate the memory, imagination, emotion, etc, it is connected to the any concept of imagery, i.e. visual imagery, auditory imagery, etc (Pradopo, 1994: 81-87).

According to Turner (1977: 7), the limitation of stylistic is the part of linguistics that concerns to the variation in using language. It is in accordance to the sentence in the news title, that this is one of the variations in using language.

According to Hartoko and Rahmanto (1980: 138), stylistic that analyzes the formal characteristic belongs to descriptive stylistic, i.e. gets close to linguistic style as the wholeness of soul expression style that is consisted in a langue, that it covers morphologically, syntactical, and semantic.

Modus of the sentence is used to investigate the function of reporting. It is used to give information, persuading, controlling the society, educating and entertaining. The sentence modus is in accordance to the way of how a sentence is expressed to the hearer (Fairclaugh, 1995). The case that happens to the title writing is that the presenter of the news states several attitudes, such as stating information to the reader, asking, or highlighting the command from the interviewee. It can be said as 'highlighting' since originally, a command is stated implicitly.

The process of building news titles results the words, phrases, clauses, or collection of clauses. After it becomes a title, the existence of words, phrases, clauses or collection of clauses can be proposed as the meaning to connect them to the body of the news. Furthermore, in building titles, there are several things to be the writers' main consideration. Those are ellipsis, substituting, reference, etc. Through the evidence of several processes, it can be concluded that a title has closely relation with the body of the news.

Moreover, on the structure, it can be identified, whether from the form of cohesion or the coherence. Halliday and Hasan (1992) show the close relation between parts in the discourse. There are two forms of relation: grammatical and cohesion-lexical. Firstly, it refers to connection of grammatical between parts of discourse; secondly, it refers to connection of lexical between parts of discourse. It can be described that cohesion-grammatical is reference, substitution, ellipsis, and conjunction. Furthermore, the lexical-cohesion is in the form of reiteration, hyponym, synonymy, antonym, and collocation.

Those concepts can help to describe or explain the result of building title if it appears the ambiguity, such as the consequence of ellipsis conjunction on the plural clause structure. Consequently, this current study does not focus in the description about grammatical or lexical cohesion. However the details of both of those cohesions are used to explain the process and the result of building title.

This study aims at describing the linguistic form of the news title in the Indonesian national newspaper. The title is identified by the discourse structure and the linguistic form of the news.

\section{Research Method}

This descriptive research describes the linguistic phenomenon that appears on the national newspapers. The objects of this research are affix, word, phrase, and clause on the title of the news and also the reference that is denoted by word, phrase, or clause of the title itself. Reference that is designated is connected to the element of the news on the formula 5 $\mathrm{W}+1 \mathrm{H}$.

The data sources of this current study are random national newspapers. Those newspapers are Jawa Pos (JP), Kompas (K), Koran Tempo, (KT), Media Indonesia (MI), and Republika (R) published in 2014. The chosen news is straight news which provides objective facts, reference on title, the photograph that completes the news, and the subtitle.

This present study can be classified as the descriptive-qualitative study. The description of the variation of the form of title is based on the level of the title filler, phonological and lexical characteristic. The title is classified based on its level. In classifying the title, this study uses segmenting immediate constituents technique to identify the level of the title: level of word, phrase, or clause. The identified title which is in the form of clause, the same technique is also applied to identify the element of sentence function such as Subject (S), Predicate (P), Object (O), Complement (C), or Adverb (A). The data is combined based on the similarities of the pattern of clause or phrase. To identify the existence of the similarities of the pattern, this study applies read-marker technique, i.e. identifying the phonological, lexical, and grammatical characteristic on the word, phrase, or clause of the title. Moreover, this study uses paraphrase technique to identify the similarities of the meaning on phrase or clause on the title and also permutation technique to get to know 
the obstinateof the position of a constituent in a clause structure. Then, in order to identify the element of the omitted clause filler, this research uses inserting technique and expansion technique, i.e. re-appearing the omitted element itself.

The variation of the linguistic form is also based on whether or not it shows the figurative language on the title. Therefore, this current study uses read-marker technique and referential identity technique. Since, in identifying the origin of the word, the data analysis technique is completed by the traditional identity technique. In order to explain the content of the title, this study uses referential identity technique.

The result of this study is presented formally, i.e. formulating by sign and symbols, and non-formal presentation, i.e. formulating by general words (Sudaryanto, 1993: 145). The formal presentation seems on the result of the description of the variation of the news title that is foregrounded by the level, such as SP for Subject-Predicate, PS for PredicateSubject, etc.

\section{Result and Discussion}

The result of the description of linguistic form found its characteristics: (a) phonology, such as pattern of utterance sound, verse, and rhyme, (b) syntactical, such as types of sentence structure, (c) lexical, such as abstract and concrete words, noun, verb, and adjective, and (d) rhetoric, such as the characteristic of using figurative language and parable (Ratna, 2009, p. 22). Furthermore, since the reach of the linguistic form on news title is not limited on the formal characteristic of the modern stylistic, therefore the researcher combines the other formal characteristics, such as morphological (e.g. affix) and several markers of grammatical conjunction that signify on reference, ellipsis, and conjunction. This study also finds these followings imagery on title.

\subsection{Phonological Characteristic}

This research differentiates between the notion of rhyme and the supra-segmental characteristic. Rhyme is in accordance to the news writer's skill in presenting rhymed title. The supra-segmental characteristic is in accordance to the use of pause, such as punctuation (comma), in order to give stress on the element of clause in front of that punctuation.

\subsection{Rhyme}

Even though it is not as potential as the syntactical characteristic, there are several examples which indicate the phonological characteristic. The characteristic is marked by the appearance of rhyme on the series of words that fill the news title.

This study proves that the title is prepared to the certain aim, i.e. fluency or ease of uttering.

(1) "Trafik Padat, Izin 12 Feri Tersendat" (BI, 5/2/2014)

In the example (1), the rhyme is in the form of syllable -dat on padat [jam] and tersendat [stagnant]. The rhyme is intended to be selected. It is understood through the utterance in the body of the news. The utterance is izin belum dapat diberikan [the license cannot be given]. The utterance has a synonymy to the izin yang tersendat [stagnant license]. Furthermore, the word tersendat [stagnant] means stop, detain, not smooth ...' (KUBI, 1982: 912).

(1a) "Kementerian Perhubungan mengklaim lalu lintas peyeberangan Merak-Bakauheni yang telah dilayani 43 armada feri merupakan rute padat sehingga penambahan kapal baru masih harus melalui izin terlebih dahulu. ... saat ini ada 12 kapal yang mengajukan permohonan izin, tetapi izin belum dapat diberikan ..." (BI, 5/2/2014)

The journalist selects to write an interesting utterance from the source of the news if the journalist does not select it by him/herself. Example (2) shows this thing.

(2) “Dusun Hilang, Warga Susah Berbilang ...” (K, 3/2/2014)

The second syllable (-lang) in hilang [missing] and the third syllable (-lang) in berbilang are actually the same, that both of them are made of three phonemes, consonant /l-/ - vowel /-a-/ - consonant /-ng/. The journalist does not prepare their own words for the title, however they use the utterance from the source of the news. The quotation (2a) proves it.

(2a) "Terserah pemerintah saja bagaimana baiknya. Tanah itu milik Perhutani," KataSrihati, ibu dari enam anak itu dengan lirih.Ia menambahkan. "Yang jelas dusunkami sudah hilang dan kami pun susah berbilang." (K, 3/2/2014)

From the example (2) it is understood that there is a verification that the journalist is interested in the interviewee's statement which is relevant to be arranged in the title. The utterance originates from the people of that district who are relocated due to slide of hills. The example is different to the following example (3).

(3) “Berguru Dahulu Sebelum Bergurau” (K, 10/11/2014)

The result of the investigation in the body of the news is that the title is taken from a proverb, such as the following quotation (3a).

(3a) "Peribahasa "berguru daulu sebelum bergurau” menggambarkan sebagian sisi industry pertahanan Indonesia. Meskipun panser anoa buatan dalam negeri telah melanglang buana, Indonesia tetap gencar "berguru” teknologi pertahanan ke negara lain. ..." (K, 10/11/2014)

In arranging the title of the news, the journalist or the writer takes into account its rhyme. The title with its fluent pronunciation makes ease that it can create relaxation. Humor is also arrayed for that reason. The relaxation is needed in 
all events especially for all prepared information that is aimed as the supplement of knowledge. According to Rohadi (2010) humor is needed in any activity. One of them is that for fading stress.

The journalist needs to understand the readers' psychic condition so the journalist can help to reduce the stress faced by the readers. Therefore, the serious things in the news can be presented lightly. The journalist can select the rhymed word or create it by using the previous text. Both of them do not belong to the research conducted by Sabardila (1997), Sumarno (2005), and Mulyati (2005).

\subsection{Supra-Segmental Characteristic}

There is an intention for the writer to give emphasizing towards the topicalized element. For example, on the clause with the element of $\mathrm{S}-\mathrm{P}$ which the $\mathrm{S}$ or $\mathrm{P}$ is topicalized. To give emphasizing, whether $\mathrm{S}$ or $\mathrm{P}$, the writer provides a comma, such as the following example (1). Through the marker, the emphasized part will be clear.

(1) “Disiplin, Kunci Kualitas Hidup Pasien” (K, 23/11/2014)

(2) “Penelitian, Kunci Menjamin Mutu” (K, 24/11/2014)

\subsection{Lexical Characteristic}

The lexical characteristic is shown by the use of figurative language. The identification shows that there are several figurative languages: (1) Parable, (2) metaphor, (3) personification, (4) metonymy, (5) hyperbole, (6) irony, (7) eufemiminsm, (8) dis-feminism, (9) imagery.

(1) "Bangkok bak Kota Hantu Saat Malam" (JP, 25/5/2014)

(2) "Hakim MK Jangan Sampai Mendidihkan Suhu Politik" (K, 22/1/2014)

(3) "PVMBG: Gunung Kelud Sedang Sakit" $(R, 12 / 2 / 2014)$

(4) "Lenovo Tantang Samsung dan Apple" $(R, 12 / 2 / 2014)$

(5) "Dunia Semarak Rayakan Imlek" ( $R, 1 / 2 / 2014)$

(6) "Gita WariskanSetumpuk Pekerjaan Rumah (MI, 1/2/2014)

(7) "Hasjrul Harahap, Menteri Penggagas HPH, Wafat" (KT, 2/2/2014)

(8) “Airin Bisa Seret Kasus Chaeri” (KT, 9/2/2014)

(9) “Mengecap Manisnya Laba Es Krim Bercita Rasa Unik" (BI, 26/2014)

\subsection{Grammatical Characteristic}

The grammatical characteristic covers the device of morphology and syntax. The device of morphology focuses on the ellipsis of affix; while the device of syntax focuses on the level of the title filler such as word, phrase, clause and sentence.

\subsection{The Ellipsis of Affix}

This finding strengthens the previous investigation, such as Sabardila (1997), Mulyati (2005), or Sumarno (2005).

(1) “Jokowi Didesak Bicara Soal Dukungan" ( $R, 16 / 2 / 2014)$

(2) "Baru 16 Instansi Umumkan CPNS" (JP, 11/2/2014)

By the ellipsis of affix ber- or $m e(N)$, it can be concluded that the variation of news title is close to the conversation which makes the utterance lighter.

\subsection{Syntactical Characteristic}

The syntactical characteristic is in accordance to the level of the title filler, the pattern of clause order, the appearance of certain punctuation, single clause, and plural clause. Example (1) is in the form of word; (2) - (4) are in the form of phrase; and (5) - (6) are in the form of minor clause. The level of word belongs to the title which is not productive.

(1) "Perdamaian" (KT, 18/11/2014)

(2) "Kisruh Rumah Belanda di Bandung" (KT, 28//1/2014)

(3) "Tentang Presiden dan Rakyatnya yang Sedang Kecewa" ( $K, 28 / 9.2014)$

(4) "12 Artis dalam Pusaran Wawan" (MI, 17/2/2014)

(5) "Ketika Binatang Ditukar dengan Innova" (KT, 3/2/2014)

(6) "Karena Warnock Tak Beruntung" (KT, 29/12/2014)

The body of the news leads the title. When there is an indistinct title, such as (1) - (6), in the complete body of the news provides the explanation. Therefore, the strength of a news is when the reader of the news would like to look for something by searching it on the sentence or paragraph in the body of the news. After searching the information provided, the reader will get the content of the news.

Title can be in the form of word, phrase, and minor clause. However, they only bring one function. It means that there is only an element in the title.

If the reader does not find anything in the body of the news, then, the news contains a weakness. Finally, a title is like a bombastic advertisement that will never show the case that being advertised. It is due to the journalist does not take into account on writing the news.

From the description above, it can be concluded that the single clause has pattern, i.e. S(Subject) P (Predicate) (O $($ Object)/C (Complement) /A1 (Adverb 1) /A2 (Adverb 2) that there are the variations, such as SP (example 7) and the variation, PS (8), SPO (9), SPC (10), SPA and the variation (11), SPOC and the variation (12), SPA1A2 and the 
variation (13), ASPC and the variation (14), SPOA1A2 and the variation (15). The function of S, in this clause is obstinate.

(7) "Kesejahteraan Tenaga Kesehatan Terabaikan" (K, 11/1/2014)

(8) "Ada yang Kader Parpol" (K, 10/1/2014)

(9) "Bawaslu Sebut Empat Potensi Kerawanan" (K, 28/1/2014)

(10) "Konsumen Pedagang Kaki Lima Diancam Denda Rp 1 Juta" (KT, 28/1/2014)

(11) "DKI Jakarta Negosiasi Ke Pusat" (K, 8/1/2014)

(12) "Maret, KPPU Jatuhkan Vonis Kartel Bawang Putih" $(K T, 1 / 2 / 2014)$

(13) "Anggoro Diperiksa Intensif Pekan Depan" (KT, 1/2/2014)

(14) "Senin, Tol Cipularang Kembali Normal” (MI, 1/2/2014)

(15) "Polisi Berantas Geng Motor dengan Patroli hingga Subuh (KT, 22/2/2014)

Then, the clause $\mathrm{S}$ is omitted and demonstrates the following variations $(\mathrm{S}) \mathrm{P}(\mathrm{O} / \mathrm{C} / \mathrm{A})$ with the details of the pattern (S)P (example 16), (S)P, (S)PO (17), (S)PC (18), (S)PK ( 19), dan (S)POC (20).

(16) "Hanya Didenda" (KT, 4/3/2014)

(17) "Waspadai Dampak Cuaca dari Timur"

(18) "Berharap Ada Obat Kuat bagi Mata Uang Garuda"

(19) "Bersepakat ke Putaran Ketiga"

(20) "Usut Peran M. S. Kaban Lewat Sopir"

The omission of S happens due to avoiding the re-stating of the utterance or the S filler is substituted to the photograph that is intended to be appeared to complete the news. However, the disappearance of S is not necessary due to that case. It can be the $\mathrm{S}$ filler is intended to be hided in the body of the news. If the readers do not continue their reading the body of the news, then they will not get the full information provided.

The complex content of the news can be packaged by the plural clause. The variation of the title presentation with the clause gives the extensive meaning in presenting the content of the news. By this presentation, the simplicity of bestowing the title will not always be an option.

The equal plural clause is collected based on the obstinateS. Some examples show that the obstinate $\mathrm{S}$ filler, whether on the first clause or the second clause. These are the pattern of the S which belongs to an obstinate S. SPC, SP (21), SPC, SPC (22), SP, SP (23), SP, SPO (24), dan SPA, SPC (25).

(21) "10 Ditemukan Tewas, 22 Hilang" (K, 28/1/2014)

(22) “Sutan Diduga Melobi, Tri Diduga Membagi” $(K, 22 / 1 / 2014)$

(23) "Rugi Sebentar, Untung Jangka Panjang" (KT, 1/2/2014)

(24) "SBY Datang, Demokrat Panen Pelanggaran" (JP, 19/2/2014)

(25) “Anak Drop Enam Jam, Ayah Terapi Berjalan” (JP, 28/2/2014)

The followings are the findings of plural clause which the $\mathrm{S}$, whether one or both is omitted. The results are the patterns of them: (S)P, conj. tapi [but] (S) PO (example 26), (S)P, (S)P conj. lalu [then] (S)P (27), (S)P conj. tapi [but] (S)P (28), (S)PC, SPC (29), SPO conj. kecuali [except] (S) (P) O (30), A(S)P, A(S)P (31), SP conj. hingga [until] (S)P (32), SP, (S)PA (33), (S)PA, (S)PC (34), (S)P, (S)P, conj. dan [and] (S)P (35), dan (S)P, (S)P (example 36).

(26) "Bukan ditambah, tapi Optimalkan Manfaat (Kontan, 28/2014)

(26a) (Penerapan alokasi anggaran pendidikan sebesar 20\% dari total belanja negara) Bukan Ditambah, tapi (kita) Optimalkan Manfaat(-nya)

(27) "Minta Dikerok, Batuk-Batuk lalu Pingsan" (JP, 2/2/2014)

(27a) (Murry) Minta Dikerok, (Dia) Batuk-Batuk, lalu (Dia) Pingsan

(28) “Tinggi tapi Kurang Berkualitas” $(K, 6 / 2 / 2014)$

(28a) (Pertumbuhan Ekonomi Tahun 2013) Tinggi, tapi (Pertumbuhan Itu) Kurang Berkualitas

(29) “Naik Motor, Perusak Pospol Bertubuh Tegap" (JP, 11/2/2014)

(29a) (Dia) Naik Motor, "Perusak Pospol (Itu) Bertubuh Tegap"

(30) PVMBG Nyatakan Radius 5 KM Aman Kecuali Desa Kuta Tengah” (MI, 12/2/2014)

(30a) PVMBG Nyatakan Radius 5 KM Aman Kecuali Desa Kuta Tengah (Tidak Aman)

(31) “Dulu Merugi, Kini Laba Rp. 4,1 Miliar” (JP, 10/2/2014)

(31a) Dulu (BPR BPK Boyolali) Merugi, Kini (BPR BPK Itu) Laba Rp. 4,1 Miliar

(32) “Korban Saat Bekerja Dibiayai hingga Sembuh" (K, 18/2/2014)

(32a) 'Korban Saat Bekerja Dibiayai hingga (Mereka) Sembuh

(33) "Potensi Besar, Belum Digarap Serius" (K, 18/2/2014)

(33a) Potensi (Pariwisata Muslim) Besar, (tapi) (Potensi Itu) Belum Digarap (secara) Serius

(34) “Diperiksa 9 Jam, Dicecar 70 Pertanyaan” (JP, 25/2/2014) 
(34a) (Istri Brigadir Jenderal (Purnawirawan) Mangisi Situmorang) Diperiksa 9 Jam, (Dia) Dicecar 70 Pertanyaan

(35) “Diseret, Diikat, dan Digigit" (MI, 25/2/2014)

(35a) (H) Diseret, (Dia) Diikat dan (Dia) Digigit

(36) “Makin Bervariasi, Makin Menarik" (BI, 27/2014)

(36a) (Produk Ammi \& Abi) Makin Bervariasi, (Produk Itu) Makin Menarik

Furthermore, the identification of plural level clause develops two assemblies, i.e. the amount of one adverb and two adverbs. The plural clause which has one adverb is in the form of A (SP), SPC (example 37), A (SP), SP conj. Dan [and] SP (38), A ((S)PC), (S)PO (39), $A((S) P C), S P O(40), \mathrm{A}((\mathrm{S}) \mathrm{P}), \mathrm{SP}(41), \mathrm{A}((\mathrm{S}) \mathrm{PA}), \mathrm{SP}(42), \mathrm{A}((\mathrm{S}) \mathrm{P}), \mathrm{SPC}(43), \mathrm{C}$ (PS), SPA (44), A ((S)(P)O), SPO (45), A(PS), SP (46), A(SPA), SP (47), PS conj sebelum [before] (S)PO(48), SPA((S)P)(49), A ((S) PC), SP (50), A ((S)PO), SPC (51), A((S)PC), SP (52), A ((S)PO), SP (53), A((S)P), SPC (54), A ((S)PO), SPO (55), and (S)PA((S)PO) (56).

(37) "Persaingan Ketat, Pileg Jadi Penentu" $(K, 8 / 1 / 2014)$

(37a) (Karena) Persaingan Ketat, Pileg Jadi Penentu

(38) Air Bah, 2 Tewas dan 27 Hilang" $(K, 8 / 1 / 2014)$

(38a) (Karena) Air Bah, 2 (Orang) Tewas dan 27 (Orang) Hilang

(39) Melawan Arah, Mengorbankan Nyawa" (K, 29/1/2014)

(39a) (Karena) (Faisal Bustamin) Melawan Arah, (Dia) Mengorbankan Nyawa(-nya sendiri)

(40) “Terlilit Utang, Ayah Tikam Anak dan Istri” (KT, 1/2/2014)

(40a) “(Karena) (Dia) Terlilit Utang, Ayah Tikam Anak dan Istri”

(41) “Tidak Banyak Kemajuan, Brahimi Kecewa” (K, 29/1/2014)

(41a) “(Karena) (Pertemuan Itu) Tidak Banyak Kemajuan, Brahimi Kecewa

(42) "Pulang dari Malaysia, Mantan TKI Dibius" ( $J P, 1 / 2 / 2014)$

(42a) (Setelah) (dia) Pulang dari Malaysia, Mantan TKI (Itu) Dibius

(43) “Tak Bisa Melaut, Nelayan Terjerat Rentenir” (KT, 3/2/2014)

(43a) (Karena) (Mereka) Tak Bisa Melaut, Nelayan Terjerat Rentenir

(44) “Ada Awan Panas, Pengungsi Takut Pulang” (MI, 3/2/2014)

(44a) (Karena) Ada Awan Panas, Pengungsi Takut Pulang

(45) "Setelah Chaeri, KPK Intai Aset Atut" (KT, 6/2/2014)

(45a) Setelah (KPK) (intai) (Aset) Chaeri, KPK Intai Aset Atut

(46) “Tak Ada Perbaikan, Atap SD Runtuh" (JP, 5/2/2014)

(46a) (Karena) Tak Ada Perbaikan (Atap SD), Atap SD (Itu) Runtuh

(47) "Polisi Saling Baku Tembak di Angkot, Seorang Terkapar" (JP, 18/2/2014)

(47a) (Karena) Polisi Saling Baku Tembak di Angkot, Seorang Terkapar"

(48) “Ada Keluhan sebelum Beri Pujian” (JP,10/2/2014)

(48a) Ada Keluhan (SBY) sebelum (Dia) Beri Pujian

(49) “Kijang KBS Mati karena Kembung” (KT, 14/2/2014)

(49a) Kijang KBS Mati karena (Binatang Itu) Kembung

(50) “Dicegah KPK, Sutan Pasrah" ( $R, 16 / 2 / 2014)$

(50a) (Karena) (Sutan) Dicegah KPK, Sutan Pasrah

(51) “Usir Demonstran, Polisi Tewas Tertembak" (JP, 19/2/2014)

(51a) (Karena) (Mereka) (MeN-)Usir Demonstran, Polisi Tewas Tertembak

(52) “Dituduh Terima Rp. 62,7 Miliar, Akil Geram” (BI, 20/2/2014)

(52a) (Karena) (Dia) Dituduh Terima Rp 62,7 Miliar, Akil Geram"

(53) “Beri Keterangan Palsu, Ajudan Rusli Ditahan" (K, 22/2/2014)

(53a) (Karena) (Dia) Beri Keterangan Palsu, Ajudan Rusli Ditahan

(54) "Mual-mual, Adik Atut Batal Disidang" (KT, 25/2/2014)

(54a) (Karena) (dia) Mual-mual, Adik Atut Batal Disidang

(55) “Temui Sekjen PBB, Menlu Venezuela Bahas Demonstrasi” (KT, 4/3/2014)

(55a) (Setelah) (dia) Temui Sekjen PBB, Menlu Venezuela (Itu) Bahas Demonstrasi” 
(56) "Tewas karena Bersihkan Abu Kelud" (JP, 19/2/2014)

(56a) "(Saji) Tewas karena (Dia) (MeN) Bersihkan Abu Kelud"

The patterns are K1(SP), SPK2 (example 57), K(S)P, K(S)PO (58), K 1((S)P(Pel)), SPK2 (59), K 1((S)P(Pel)), SPK2

(60), K 1((S)P(Pel)), SPK2 (61), K1(SPO), SPK2 (62), K(S)P, K(S)PPel (63), K1(S)P(O), dan (S)PK2 (64).

(57) “Banjir Surut, Pengungsi Pulang ke Rumah" (R, 1/2/2014)

(57a) (Setelah) Banjir Surut, Pengungsi Pulang ke Rumah

(58) “Dulu Meratap, Sekarang Pasang Spanduk Selamat Datang Banjir" (JP, 4/2/2014)

(58a) Dulu (Warga Bojonegoro) Meratap, Sekarang (Mereka) Pasang Spanduk Selamat Datang Banjir

(59) “Tergenang, Jalan Terputus Dua Bulan” (JP, 6/2/2014)

(59a) (Karena) (Jalan) Tergenang (Air), Jalan Terputus Dua Bulan

(60) “Karena Kelaparan Mie Disantap tanpa Dimasak" (MI, 19/2/2014)

(61) "Rumah Rusak, Korban Banjir Tinggal di Emperan" (JP, 11/2/2014)

(61a) (Karena) Rumah Rusak, Korban Banjir Tinggal di Emperan

(62) "Idham Tak Bawa Dokumen Asli, Pemeriksaan Ditunda Lagi” (KT, 25/2/2014)

(62a) “(Karena) Idham Tak Bawa Dokumen Asli, Pemeriksaan(-nya) Ditunda Lagi”

(63) “Dulu Merugi, Kini Laba Rp. 4,1 Miliar” (JP, 10/2/2014)

(63a) Dulu (BPR BKK Boyolali) Merugi, Kini (BPR Itu) Laba Rp 4,1 Miliar

(64) “9 Jam Menunggu, Ditemui 10 Menit” (KT, 18/2/2014)

(64a) (Selama) 9 Jam (Narti) Menunggu, (Dia) Ditemui (Selama) 10 Menit

\subsection{Sentence Modus}

The discourse of a news brings out a main function: communicative function. It means the delivering of information from the writer to the reader. Besides declarative function, there are two other kinds of modus: command (1) and question (2).

(1) “Pertimbangkan PT di Bawah Kemristek" (K, 8/2/2014)

(2) "Doping?" (KT, 10/12/2014)

The superiority of commanding is that the title directly gives higher understanding if it is compared to the indirect command, since it covers many speakers from any realm. An indirect command needs sensitivity. Since, it aims at covering many readers, therefore, an indirect command is less risky in presenting the message.

The finding shows that the title is developed by the module of question (example 2). Towards the uncertain news, a journalist must be careful in reporting it by selecting a question sentence. It is based on the content of the news that "the result of doping test has not been released" as explained in the title of the news, such as (2a).

(2a) "Dari lima yang dipilih untuk melakukan tes doping, hanya saya yang harus memberikan sampel urine dan darah.Sedikit aneh, bukan?" begitu Messi menuliskan di akun Instagram. ....

"Ada apa dengan Messi? Apakah ini hubungannya dengan kehebatannya dalam ... dia membuat hat-trick ke gawang Espanyol. ...

"Hasil tes doping belum diketahui hasilnya. ..." (KT, 10/11/2014)

3.9 Cohesion of Title - Body of the News

It has been explained previously that the incomplete news content on the title indicates the title as the terrace of the news. The completeness of the message is packaged in the body of the news. The following example relates to the clarity of the news content. Title that contains incomplete information is due to the decision of pronoun. The reference of pronoun is provided in the body of the news. Therefore, between the title and the body of the news has correlation of reference, such as (1) - (2). The other cohesion is proved through the conjunction akhirnya [finally], such as in (3).

"Mereka Berkorban Untuk Demokrasi” (K, 2/2/2014)

'They Sacrifice for Democracy'

(2) "PakHakim, Saya sudah Renta dan Darah Tinggi" (MI, 4/2/2014)

'Judge, I am already Old and Have High Blood Pressure'

(3) “Akhirnya, Ada Kepastian" (JP, 16/2014)

'Finally, there is a Certainty'

The readers will rapidly identify the reference if they continue their reading to the body of the news. If the discourse is completed with photograph, the reference refers to the source of the news in the photograph.

The election of pronoun saya [I] can juxtapose the readers to the source of the news. Otherwise, in using mereka [they] is positioned as mediator. In the use of first person pronoun, then the existence of the reader is not seen. This variation is important to avoid the monotony of the presentation. 
The cohesion of title-body of the news is marked by the conjunction akhirnya [finally]. It is different to the previous titles which show the cohesion through the conjunction karena [because], setelah [after], ketika [when], or [atau], and dan [and].

The appearance of the conjunction akhirnya [finally] showsh that the text contains the news content about the process of an event. The report with the marker akhirnya [finally] marks the end of the process, such as the following quotation (1a).

(1a) "Dengan adanya kepastian kontrak, membuat lega para penggawa tim yang sudah tujuh kali juara perserikatan tersebut. "Kalau sudah jelas seperti ini, sebagai pemain tentu jadi lega. Ini memang yang kita harapkan sejak dulu, "ungkap ... Tinton Suharto." (JP, 16/2/2014).

The writer of the news is like a story writer who presents the story continuously on the next edition. By selecting the conjunction akhirnya, the journalist wants to explain the exhaustiveness of the news. The completeness of the presentation becomes the demand of the readers. The conjunction akhirnya gives certainty about the end of the news, since it is a conclusion of the written news. The title with the marker akhirnya and its synonymy (: maka, jadi, karena itu, oleh karena itu, etc) (Sidu, 2013: 133) gives the characteristics of the existence of communication intensity between the writer and the readers.

The syntactical characteristic which is in the form of word, phrase and clause strengthens what Sabardilla (1997), Sumarno (2005), and Mulyati (2005) have found. From the levels, the element of the news is identified. This finding highlights the characteristic of straight news which is unadorned and objectively presents the fact based on the element of $5 \mathrm{~W}+1 \mathrm{H}$.

Furthermore, the sentence modus can explain the attitude of the writer. Also, the analysis of lexicon resulted by the title which has figurative language will be investigated several functions of title, such as giving information, influencing, educating, etc. The investigation of title to the body of the news results the cohesion within them. The ellipsis of $\mathrm{S}$ on the single or plural clause proves the correlation.

Therefore, the omission of S is not judged as divergence. This finding is different to what Sumarno (2005) has found which judged the ellipsis as the form of discrepancy. The function of omitted S on the single clause can be tracked to the other clauses. In addition, the constituent which is omitted on the title can be found in the body of the news. Hence, the news content in the body of the news is proper to be built completely so that it can be positioned as the source of the investigation of the news content.

This current study can be compared to the previous investigations, such as Sabardila (1997), Sumarno (2005), and Mulyati (2005). Sabardila (1997) utilized the limited newspapers. Further, Sabardila's (1997) findings did not identify the source of the news and the utterance resulted. Therefore, her investigation did not result any assessment related ti the title which is based on the fact or opinion and the ideology of the newspaper(s). Sabardila's (2016) findings, as has been written in this article, are based on the five newspapers as the data source. Moreover, it identifies the linguistic form (title and the structure of the discourse of the news), the position of the news, and the any factors which foreground the differences of the packaging of the news content.

Sumarno (2005) found the structure of the clause which contained the ellipsis which was judged as the form of alteration, syntactical instrument, and the existence of the use of the short words. Then, Sabardila's (2016) research varies on the structure of the clause since the number of the data which are analyzed. The instrument of the syntax, such as topicalization, is revealed through the investigation of Sabardila (2016).

Mulyati (2005) found the limited levels (phrase, clause, and sentence) and the ellipsis of affix me(N)- and the phrase. Several research findings in Mulyati (2005) are such as phrases, clauses, and sentences (: simple sentence and the complex sentence). This is in accordance to what had been found by Sabardila (1997) and Sumarno (2005). Mulyati's (2005) research about the ellipsis was only in the area of the affix me(N)-, words, or the more simple phrases if it is compared to Sumarno (2005) since the ellipsis in his research found the ellipsis in the area of clause. Sabardila (2016) is in the form of the straight news, process of the title formation, and the position of the title in the body of the news, the ellipsis of minor clause and main clause, and the title contained in the important message or just the front cover of the news. Subsequently, the process of the title formation is based on the level of the phonology, morphology, and word, semantic, and discourse.

\section{Conclusion}

$J P, K, K T, M I$, and $R$ have shown the linguistic form comprehensively: from phonological to the discourse. Furthermore, they have exposed the sentence modus and cohesion device between the title and the body of the news. It is due to the fulfillment of any functions, such as giving information, persuading, keeping the relationship between the journalist and the reader, or giving response to the phenomenon. The variation of the title is inclined to use clause, whether single or plural clause. The level of clause can give clarity about the content of the news.

The title of the news gives focus on the element of what. It can be explained from the description of the variation of clause, whether single or plural clause that ellipses the subject. However, the pattern of single clause can be an option in arranging the title of the news. By its simplicity, the content of the news can be understood easily by the readers. Furthermore, the presenter of the news can touch it with the sense of humor, so the thoughtful news content can be delivered lightly. 


\section{References}

Baryadi, I. P. (2007). "Urutan Klausa dalam Kalimat Majemuk Subordinatif Bahasa Indonesia.” Humaniora: Jurnal Budaya, Sastra, dan Bahasa, 19(3), 224-231.

Fairclough. N. (1995).Media Descourse. London: Edward Arnold.

Folley, W. A. (2007). A Typology of Information Packaging in the Clause.Cambridge.

Halliday, M.A.K \& Hasan, R. (1992). Bahasa, Konteks, dan Teks: Aspek-aspek Bahasa dan Pandangan Semiotik Sosial. Terjemahan oleh Barori Tou. Yogyakarta: Gadjah Mada University Press.

Hartoko, D. (1986). Pemandu di Dunia Sastra. Yogyakarta: Kanisius.

Kesuma, T. (2005). "Realisasi Kategorial dan Semantis Fungsi Keterangan dalam Bahasa Indonesia". Dalam Humaniora: Jurnal Budaya, Sastra, dan Bahasa, 17(3), 261-276.

Lia Marliana, N. (2009). "Problematika Penggunaan Ragam Bahasa Jurnalistik pada Media Massa dan Implikasinya terhadap Pembinaan Bahasa Indonesia di Masyarakat.dalamDiksi: Jurnal Ilmiah Bahasa, Sastra, dan Pengajarannya, 16(2), 143-152.

Mulyati, S. (2005). "Tipe-tipe Judul Berita Surat Kabar Berbahasa Indonesia di Surakarta : Kajian Struktural dan Sosiolinguistik”. Thesis.Department of Linguistics Study.Fakultas Ilmu Budaya Universitas Gadjah Mada Yogyakarta.

Pike, K.L., \& Pike, E.G. (1977). Grammatical Analysis. Dallas: The SIL.

Pradopo, R.D. (1994). “Stilistika” dalam Jurnal Humaniora.No. 1.Tahun 1994.

Ratna, N.K. (2009). Stilistika: Kajian Puitika Bahasa, Sastra, dan Budaya. Yogyakarta: Pustaka Pelajar.

Rohmadi, M. (2010). “Strategi Penciptaan Humor dengan Pemanfaatan Aspek-aspek Kebahasaan”.Humaniora: Jurnal Budaya, Sastra, dan Bahasa, 22(3), 286-298.

Sabardila, A. (1997). "Relevansi Judul dengan Tubuh Berita (Studi Kasus Surat Kabar Jawa Pos)".Thesis.Department of Linguistics Study.Gadjah Mada University.

Sidu, L.O. (2013). Sintaksis Bahasa Indonesia. Kendari: Unhalu Press.

Sudaryanto, X. (1993). Metode dan Teknik Analisis Bahasa. Yogyakarta: Duta Wacana University Press.

Sumarno, J. (2005). "Judul Berita Surat Kabar: Sebuah Kajian Sintaksis." Thesis.Department of Linguistics Study.Faculty of Culture Science.Gadjah Mada University.

Wojowasito, X. (1982). Kamus Umum Bahasa Indonesia. Jakarta: PN Balai Pustaka.

Turner, G.W. (1977). Stylistic. Harmoundsworth Middlesex: Penguin Books.

Wijana, I. P. (2011). "The Development of Bahasa Indonesia in Multicultural Context: A Case Study of Adoloscent's Slang”. In Humaniora. Jurnal Budaya, Sastra, dan Bahasa, 23(1), 71-78. 